\title{
Discussion Paper No. 13-054 \\ Do First Mover Advantages for Producers of \\ Energy Efficient Appliances Exist? \\ The Case of Refrigerators
}

Thomas Cleff and Klaus Rennings

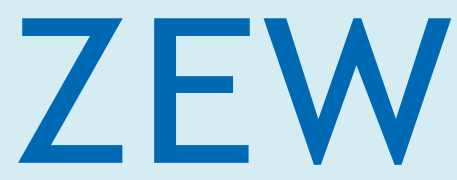

Zentrum für Europäische Wirtschaftsforschung $\mathrm{GmbH}$

Centre for European

Economic Research 


\title{
Discussion Paper No. 13-054 \\ Do First Mover Advantages for Producers of Energy Efficient Appliances Exist? The Case of Refrigerators
}

\author{
Thomas Cleff and Klaus Rennings
}

Download this ZEW Discussion Paper from our ftp server:

http://ftp.zew.de/pub/zew-docs/dp/dp13054.pdf

Die Discussion Papers dienen einer möglichst schnellen Verbreitung von neueren Forschungsarbeiten des ZEW. Die Beiträge liegen in alleiniger Verantwortung der Autoren und stellen nicht notwendigerweise die Meinung des ZEW dar.

Discussion Papers are intended to make results of ZEW research promptly available to other economists in order to encourage discussion and suggestions for revisions. The authors are solely responsible for the contents which do not necessarily represent the opinion of the ZEW. 


\section{Non-technical summary}

Energy efficiency regulation is an important driver for innovations in environmental technologies. Improvements of energy efficiency do not only contribute to reach environmental policy targets, they can be furthermore economically profitable. Private households can reduce their costs in the long term by using efficient household appliances. According to the German Federal Environmental Ministry, the world market for energy efficient household appliances had 2007 a volume of 105 billion euro, with a German market share of 9 percent and expected growth rates of 3 percent until 2020. But how can the specific competitive position on this market be assessed for German producers, and how strong is the competitiveness from firms coming from emerging economies? For answering these questions we analyze national lead market factors in the case of refrigerators. We develop indicators for the factors of countries which are seen as important in the literature for reaching a leading international position: Comparative advantages regarding prices and demand, country's reputation for technological expertise and as a problem solver, export advantages and a competitive market structure. Also environmental regulations and supply side factors are considered as framework conditions.

As our results show, Germany has the most lead market potentials for energy-efficient refrigerators, followed by Korea und Italy. A producer on the German lead market is the firm BSH Bosch and Siemens Home Appliances $\mathrm{GmbH}$. According to BSH first mover advantages for high-tech energy efficient appliances can be realized on the German market. This is backed by high energy efficiency standards in Europe which diffuse after some years to other countries.

Since the pay-off time for energy efficient household appliances is with 7 to 10 years quite long, also a cost strategy with low prices can be successful. Especially in the case when the price of electricity and the national income are low. Markets for such products are for example in Asia and Russia.

Producers use the existence of both strategy options to operate with different brands and product lines in different market niches at the same time. For firms in countries that do not have sufficient lead market potentials, innovations in energy efficiency must be targeted to fit the preferences of users in the lead market. The screening of the lead market can take on varying degrees of intensity. A good way for a company to establish ties with a lead market is via producers with long experience on the Lead Market. It can be realised through a simple sales cooperation with local producers or a merger with a local producer of the lead market. As an example, competitive pressure for firms on the lead market comes from appliances with low prices and high energy efficiency, especially from competitors in Turkey. The Turkish firm Arçelik A.Ş., originally known as a producer of low cost appliances, developed in the past innovative, eco-efficient products under the brand name BEKO. The refrigerators are produced in Turkey, without a strong domestic home market for energy efficient appliances. The strategy shows that an orientation at the lead market can be a promising innovation strategy for "second mover". 


\section{Das Wichtigste in Kürze}

Energieeffizienzregulierungen im Zuge des Klimawandels gelten als wichtiger Treiber für Innovationen im Bereich der Umwelttechnologien. Verbesserungen der Energieeffizienz tragen dabei nicht nur zur Erreichung von Umweltzielen bei, sie rechnen sich nicht selten auch ökonomisch. Haushalte können beispielsweise ihre Kosten langfristig senken, indem sie sich für energieeffiziente weiße Ware entscheiden. Der Weltmarkt für energieeffiziente Haushaltsgeräte hatte 2007 nach Angaben des Bundesumweltministeriums ein Volumen von 105 Mrd. Euro, bei einem Weltmarktanteil Deutschlands von 9 Prozent und prognostizierten Wachstumsraten von 3 Prozent jährlich bis 2020.

Aber wie sind die spezifischen Wettbewerbschancen deutscher Hersteller auf dem Weltmarkt für energieeffiziente Technologien zu beurteilen und welche Gefahr droht von Wettbewerbern aus Schwellenländern? Zur Beantwortung dieser Fragen führen wir eine Analyse nationaler Lead Market-Faktoren am Beispiel energieeffizienter Kühlschränke durch. Dabei werden Indikatoren verwendet, die in der Literatur als besonders wichtig für eine internationale Führungsposition eines Landes erachtet werden: Relative Vorteile bei Preisen und Nachfrage, ein guter Ruf des Landes als Technologieentwickler, Exportvorteile sowie eine wettbewerbsfördernde Marktstruktur. Auch die Umweltregulierung sowie Angebotsbedingungen wie beispielsweise die Forschungsinfrastruktur werden als Rahmenbedingungen berücksichtigt.

Unsere Ergebnisse zeigen, dass Deutschland die meisten Lead Market Potentiale für energieeffiziente Kühlschränke besitzt, gefolgt von Korea und Italien. Ein Unternehmen auf dem deutschen Lead Market ist die Firma BSH Bosch und Siemens Hausgeräte $\mathrm{GmbH}$. Aus der Perspektive von BSH lassen sich durch Technologieführerschaft auf dem deutschen Markt Pioniergewinne für High-Tech energieeffiziente Geräte erzielen. BSH profitiert dabei von der Vorreiterrolle Europas mit hohen Energieeffizienzstandards, die sich zeitversetzt in andere Länder ausbreiten.

Da aber die Amortisationsdauer für energieeffiziente Haushaltsgeräte mit 7 bis 10 Jahren sehr lang ist, kann auch eine Strategie der Preisführerschaft mit günstigen Produkten erfolgreich sein. Diese zweite Strategieoption ist dann erfolgreich, wenn der Strompreis und die nationale Kaufkraft gering sind. Märkte für diese Produkte liegen beispielsweise in Asien oder in Russland.

Hersteller nutzen die Existenz beider Strategieoptionen, um durch Aufbau verschiedener Marken- und Produktlinien die unterschiedlichen Marktnischen gleichzeitig bedienen zu können. Firmen aus Lag-Märkten müssen dabei die Präferenzen der Konsumenten für Energieeffizienz auf dem Lead Market bei der Entwicklung von Innovationen antizipieren. Die Beobachtung des Lead Markets kann dabei von einfachen „Horchposten“ bis zur Kooperation mit bzw. der Akquisition von Produzenten auf dem Lead Market reichen. So entsteht den deutschen Herstellern Konkurrenz durch kostengünstige Geräte mit gleichzeitig hoher Energieeffizienz, insbesondere durch Wettbewerber aus der Türkei. Der türkische Produzent Arçelik A.Ş., der ursprünglich ausschließlich eine Reputation für kostengünstige Geräte besaß, überraschte in der Vergangenheit mit innovativen, öko-effizienten Lösungen unter dem Markenname BEKO. Die Geräte werden in der Türkei produziert, ohne dass dort ein starker Nachfragemarkt für energieeffiziente Technologien existiert. Die Strategie von Arçelik zeigt, dass eine Orientierung am Lead Markt eine erfolgversprechende Innovationsstrategie für technologische „Second Mover" sein kann. 


\title{
Do First Mover Advantages for Producers of Energy Efficient Appliances exist? The Case of Refrigerators
}

\author{
Thomas Cleff \\ Pforzheim University \\ Centre for European Economic Research (ZEW), Mannheim \\ Klaus Rennings \\ Centre for European Economic Research (ZEW), Mannheim
}

\begin{abstract}
Energy efficiency regulation is an important driver for innovations in environmental technologies. Improvements of energy efficiency do not only contribute to reach environmental policy targets, they can be furthermore economically profitable. E.g. private households can reduce their costs in the long term by using efficient household appliances. But how can the specific competitive position on this market be assessed for German producers, and how strong is the competitiveness from firms coming from emerging economies? We analyse - as an example - the global refrigerator market, using the lead market approach for environmental innovations.

As our results show, Germany has the most lead market potentials for energy-efficient refrigerators, followed by Korea und Italy. First mover advantages for high-tech energy efficient appliances can be realised on the German market. This is backed by high energy efficiency standards in Europe which diffuse after some years to other countries.

Since the pay-off time for energy efficient household appliances is with 7 to 10 years quite long, also a cost strategy with low prices can be successful. Especially in the case when the price of electricity and the national income are low. Markets for such products are for example in Asia and Russia.

Producers use the existence of both strategy options to operate with different brands and product lines in different market niches at the same time. For firms in countries that do not have sufficient lead market potentials, innovations in energy efficiency must be targeted to fit the preferences of users in the lead market. The screening of the lead market can take on varying degrees of intensity. A good way for a company to establish ties with a lead market is via producers with long experience on the Lead Market. It can be realised through a simple sales cooperation with local producers or a merger with a local producer of the lead market.
\end{abstract}

Keywords: Household appliances, energy efficiency, refrigerators, lead market, first mover

JEL classification: Q55, O33, Q01, Q58 


\section{Introduction}

Energy efficiency regulation is an important driver for innovation in environmental and sustainable technologies. Increasing energy efficiency contributes not only to reach environmental targets. Furthermore it can be economically profitable. Private households can e.g. reduce their costs by using efficient household appliances or lighting. It is therefore not surprising that the global market for energy efficiency technologies is expected to become an important future market that should double from $€ 540$ billion in 2007 to $€ 1.030$ billion in 2020 (BMU, 2009; BMU/UBA, 2011).

Against this background, this paper analyses lead market potentials of different countries for energy efficient refrigerators ${ }^{1}$. As it is common in a globalized economy, emerging countries have entered the market and have become relevant competitors. Figure 1 shows that the Chinese market growth rates for the refrigerator stock outperform clearly the ones of the European markets for a longer period of observation between 2000 and 2009.

Figure 1: Growth Rate of the Refrigerator Stock [2000-2009]

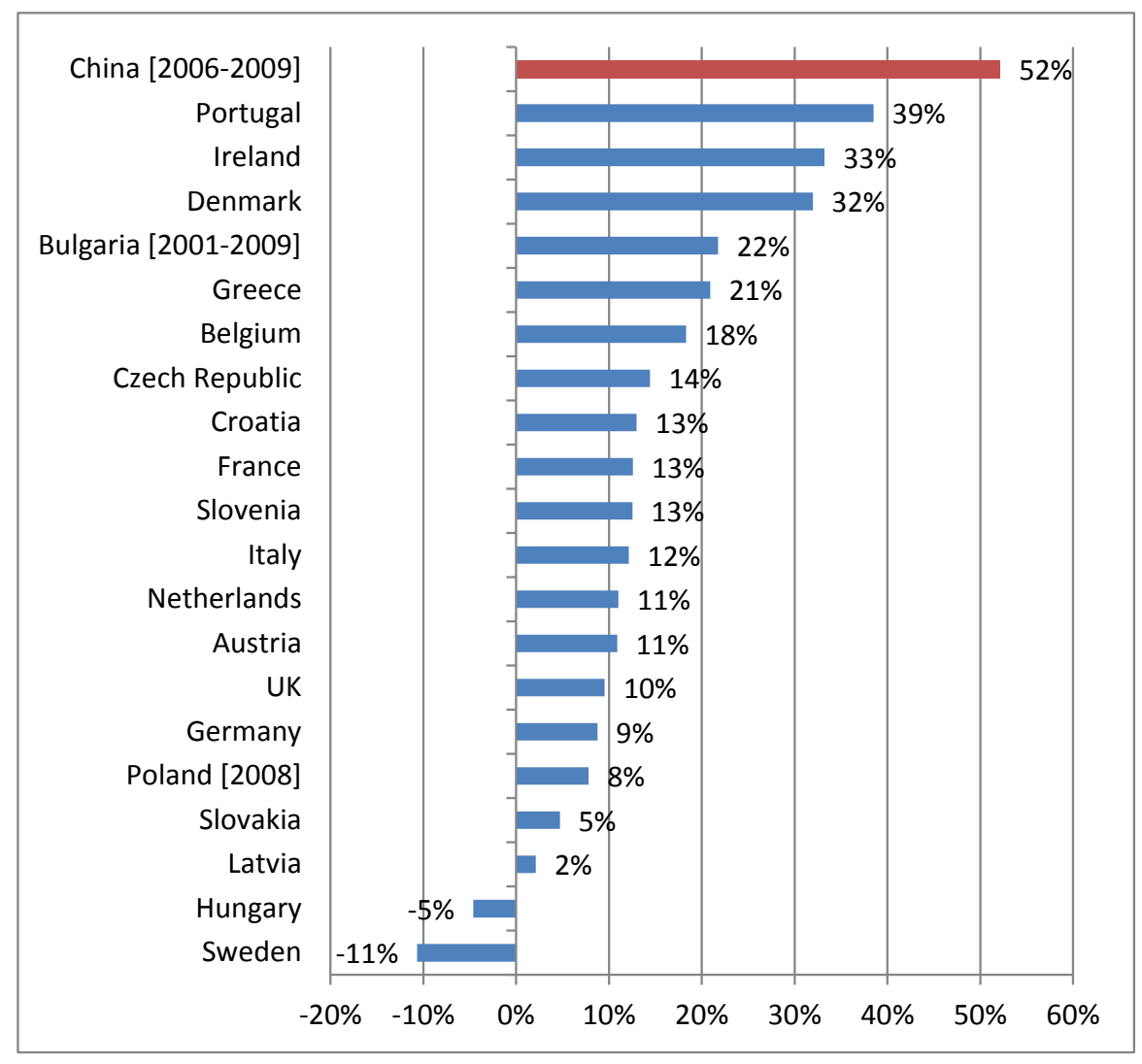

Source: Odyssee Database (n.y.) and CNIS (2010 and 2011).

1 This study focuses on refrigerators. In case there exist no individual data for refrigerators, respective average values of the household appliances industry will be taken. 
In the group of the fastest growing emerging markets including Brazil, Russia, India, and China (BRIC), China is catching up much faster than the other nations in the field of durable consumption goods. For refrigerators, the Chinese catching-up rate is about two per cent points per year compared to the developed countries (Waheeduzzaman, 2011 , p. 144). On the other hand, markets are saturated in developed countries (Waheeduzzaman, 2011). The question is if they are lagging behind the producers from developed countries, or if and how far they are catching up?

In this paper we will apply an indicator-based approach to measure the relevance of different lead market factors. We will use in particular the lead market approach for environmental innovations of Beise and Rennings (2005) who identified six success factors for such markets: Comparative price and demand advantages, a high reputation in environmental technology (transfer advantage), similar market conditions (export advantage), a competitive market structure and ambitious environmental regulation. This approach will be described in section 2. In section 3 we will explain our indicators to measure the relevance of lead market factors for the household appliances and refrigerator industry. Section 4 presents the resulting indicators. Section 5 reflects the findings against the results of a qualitative field study (including the analyses of annual reports and interviews with company representatives), in which we have analysed the market strategies of selected refrigerators producers. Finally, section 6 summarises the lead market potentials and derives policy recommendations.

\section{Lead market analysis}

The lead market approach was first suggested in the late 1980s by Porter (1986) and Bartlett/Ghoshal (1990) and has received increasing attention during the last years (CEC, 2006). A lead market can be defined as a country where users prefer a specific innovation design that not only appeals to domestic users, but can subsequently be commercialised successfully in other countries as well. The technical design preferred by the Lead Market squeezes out other designs initially preferred in other countries and becomes the globally dominant design.

A lead market model has to give an answer to the question under which circumstances a country's market characteristics are appropriate to the adoption of technological innovations that will succeed internationally and mark out the technological path to be followed worldwide. We will use the approach for environmental innovations of Beise and Rennings (2005) who identified six success factors for Lead Markets:

- The demand advantage of a country relates to an early anticipation of developments that later become global trends. It can be expressed as the proportion of a country's total consumption accounted for by these products. The difference between different countries' markets does not lie in the direction in which they develop, but merely in the speed with which they move in the direction of the global trend. 
- It is obvious that decreasing prices of goods accelerate the diffusion of these goods. Price advantages refer to the situation when a certain innovation can squeeze out other innovation designs by a lower price (Levitt, 1983). A price advantage of a Lead Market will occur only if the price difference is large enough to exceed the transaction costs incurred in changing over to cheaper innovation design.

- The key characteristic of a Lead Market is that innovations realised there will not be limited to a certain country, but should be well-suited for export. An export advantage in the past may encourage innovators to make their products suitable for international markets.

- Empirical studies show that sharp competition (market structure advantage) tends to facilitate the emergence of Lead Markets (Beise, 2001). Customers in competitive markets can be "choosier" than in oligopolies or monopolies (Porter, 1990). Competition can therefore be understood as a process, by which all the participants attempt to achieve a better innovation design.

- A country's market has a transfer advantage if it raises the perceived utility of customers worldwide. The reputation and sophistication of the Lead Market's users is considered to be a hallmark for high-quality innovation designs. The quality of demand is especially determined by user's know-how and experience with similar products (Beise et al., 2002). We also take supply-side factors such as patents into account. The reason is that a country's household appliances industry may benefit from its lead market position only if the supply-side is able to respond to the high lead market potentials for all lead market factors. The relevance of the supply side is discussed more deeply in Rennings/Cleff (2011) and Tiwari/Herstatt (2011).

- The regulation advantage is especially important for environmental innovations, since demand alone may not be sufficient for a success on the market due to the fact that the product has at least partially a public good character (Beise and Rennings, 2005). Thus they need some regulatory support. "A country has a regulation advantage if the legal framework allows companies to plan on a mid- and long-term scale and at the same time exerts pressure on firms to come up with innovative ideas" (Rennings and Smidt, 2010).

\section{Data and indicators}

\section{Demand advantage}

It is possible to measure the sector-specific demand specialization of a country (i) by subtracting the average share of total demand within the countries under consideration from the share of demand for one country:

$$
\mathrm{DA}_{\mathrm{i}}=\frac{\mathrm{C}_{\text {household appliances, } \mathrm{i}}}{\mathrm{C}_{\text {all products }, \mathrm{i}}}-\frac{\mathrm{C}_{\text {household appliances, all countries }}}{\mathrm{C}_{\text {all products, all countries }}}
$$


The data about country's demand can be estimated from international Purchasing Power Parities (PPP) statistics. PPP statistics provide information on total domestic demand (expenditure) and prices for a large variety of products. Data for major household appliances are available for 2005 upon request from different international institutions (Eurostat/OECD, 2012; Worldbank ICP, 2011; CIC, n.Y.).

\section{Price advantage}

Price information about household appliances is also available for 2005 from international purchase power parity (PPP) statistics. National currencies were converted to Euro (EU-27) using average annual exchange rates. The negative logarithmic quotient of the household appliances industry's relative PPP level in a certain country $k$ and the average price level of all sectors $\left(\Sigma S_{l}\right)$ for the same country can serve as an direct indicator for price differences between countries in the household appliance industry.

$$
\ln \left(\frac{\mathrm{PPP}_{\mathrm{k}}^{\mathrm{T}}}{\sum_{\mathrm{PPP}_{\mathrm{k}}^{\mathrm{l}=1} \mathrm{~S}_{1}}^{\mathrm{n}}}\right) \cdot(-1)
$$

A relative PPP level calculated in this way controls for country-specific differences in pro-capita income and the different price levels that result.

In order to answer the question about price-related demand factors for energy efficient household appliances, it is vital to take account of complementary factor costs for electricity. Research results could show that the higher the relative factor-prices, the higher are the cost savings in the demand of energy efficient products. The factor costs are measured through costs for electricity (including taxes) controlled for the country's PPP.

\section{Export Advantage}

To assess the export advantage in the refrigerator manufacturing industry we have to evaluate the extent of export success for each country. We do this by examining export shares of the entire world trade for the most important refrigerator producing countries in the world using the respective SITC4 code 77521 of the UN Comtrade Database. An export share in world trade of five percent or more will be regarded as a market with an export advantage. This corresponds at the same time to the mean value of the top-20 export nations.

\section{Market Structure Advantage}

We want to analyse how an innovation can exist successfully on a high number of foreign markets. Thus, there is not the absolute sum of exports in the centre of analysis, but the concentration of these exports to different countries. The higher the concentration of exports, the lower is the global export capability of this market and the lower therefore is the market structure advantage. The grade of export concentration was determined with the Herfindahl Index for the export shares of total export of the respectively 20 largest export partners of a country. A Herfindahl Index smaller than 0.74 (av- 
erage Herfindahl Index of all countries) shows a market structure advantage, a value greater than 0.74 stands for a disadvantage:

$$
\operatorname{MSA}_{j}=\sum_{i=1}^{20}\left(\frac{\operatorname{Exp}_{i}}{\sum_{i=1}^{n} \operatorname{Exp} p_{i}}\right)^{2}
$$

\section{Transfer Advantage}

Patent statistics, moreover, emphasize to what extent a company is able to secure legally their own know-how and the customers' know-how in the form of patents. This becomes apparent through indicators like worldwide patent shares in the field of technology or the Relative Patent Advantage (RPA) for the product groups of household appliances using the Fraunhofer ISI patent database (Walz et al., 2010).

$\mathrm{RPA}_{i j}=100 \cdot \operatorname{tanhyp} \ln \left[\frac{\left(\frac{p_{i j}}{\sum_{i} p_{i j}}\right)}{\left(\frac{p_{i j}}{\sum_{j} p_{i j}}\right)}\right]$

\section{Regulation Advantage}

In all countries that are included in our analysis, mandatory energy efficiency labels and minimum performance standards (MEPS) have been introduced to foster the demand for energy efficient household appliances (Harrington and Damnics, 2004). We measure the regulation advantage by calculating the negative difference between the

(1) year of introducing the first mandatory comparative label in a given country compared to the respective median of all countries and

(2) the negative difference between the year of introducing the first MEPS in a given country compared to the respective median of all countries

Only if both negative differences have a positive value is a country considered an early adopter of environmental regulation.

\section{Results}

Figure 2 contrasts price specialization for household appliances with factor costs for electricity (including taxes) controlled for the country's PPP. In countries such as Germany (DE), Denmark (DK), Japan (JP) and Italy (IT) (see upper right quadrant of the portfolio) the relative prices for household appliances are not only below average but 
also the relative costs for electricity are above average so that customers are likely to have a greater incentive to buy energy efficient products.

Figure 2: Price Advantages and Disadvantages of different household appliances markets

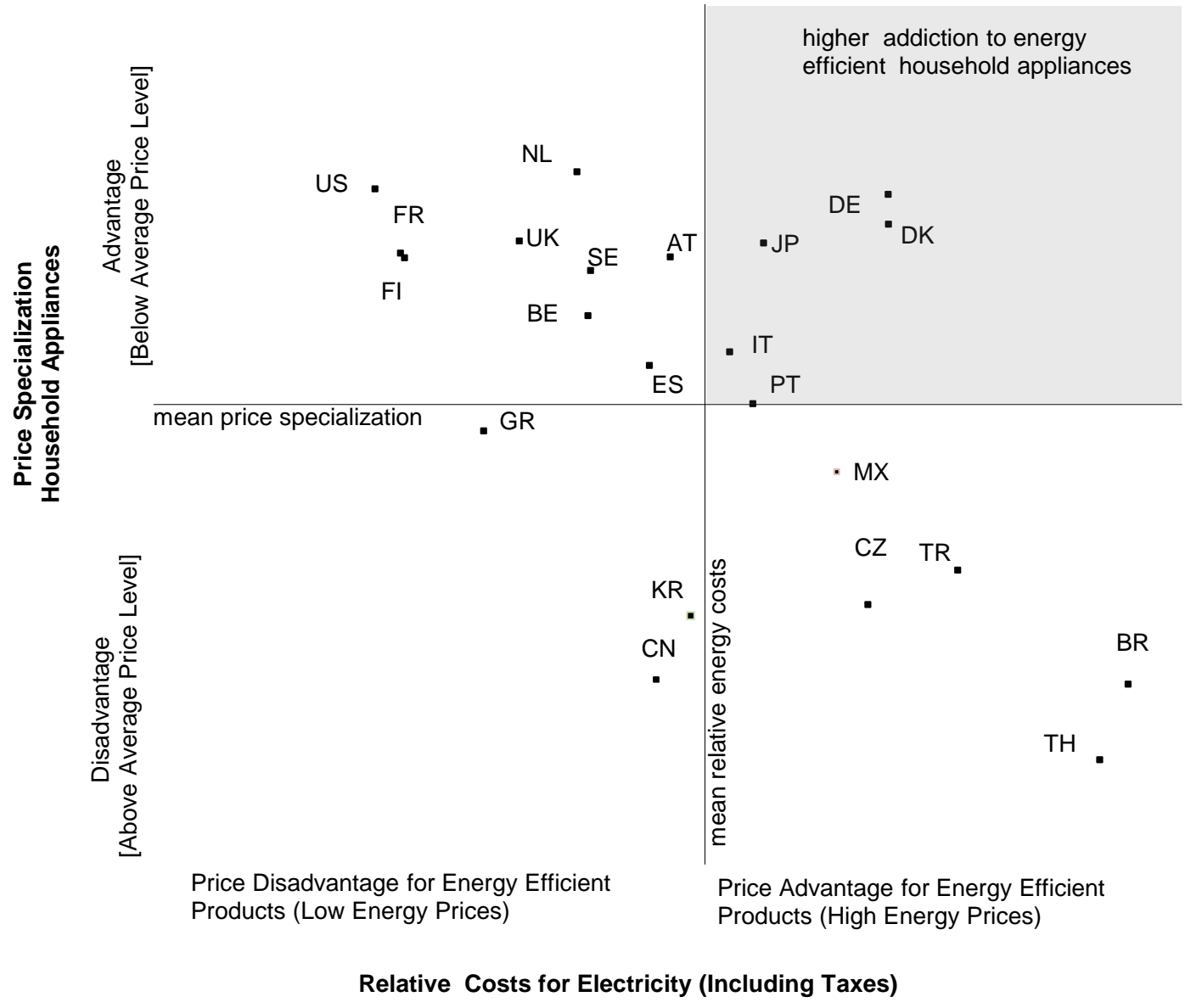

Source: UK Department for Energy and Climate Change 2012; US Energy Information Administration; Eurostat/OECD PPP-Statistics; Worldbank ICP 2011; Penn World Tables. Own calculations.

In Figure 3, the relative PPP level is plotted against demand specialisation for all countries. The best fit is a second order polynomial least squares regression to find out which countries show an above average propensity to consume for a given price. The countries that are of interest to us are those located above the regression line. Innovation designs that exploit this price elasticity can spread quickly and make use of market size advantages to increase their ability to compete on price. 
Figure 3: Price advantages and demand specialization for household appliances

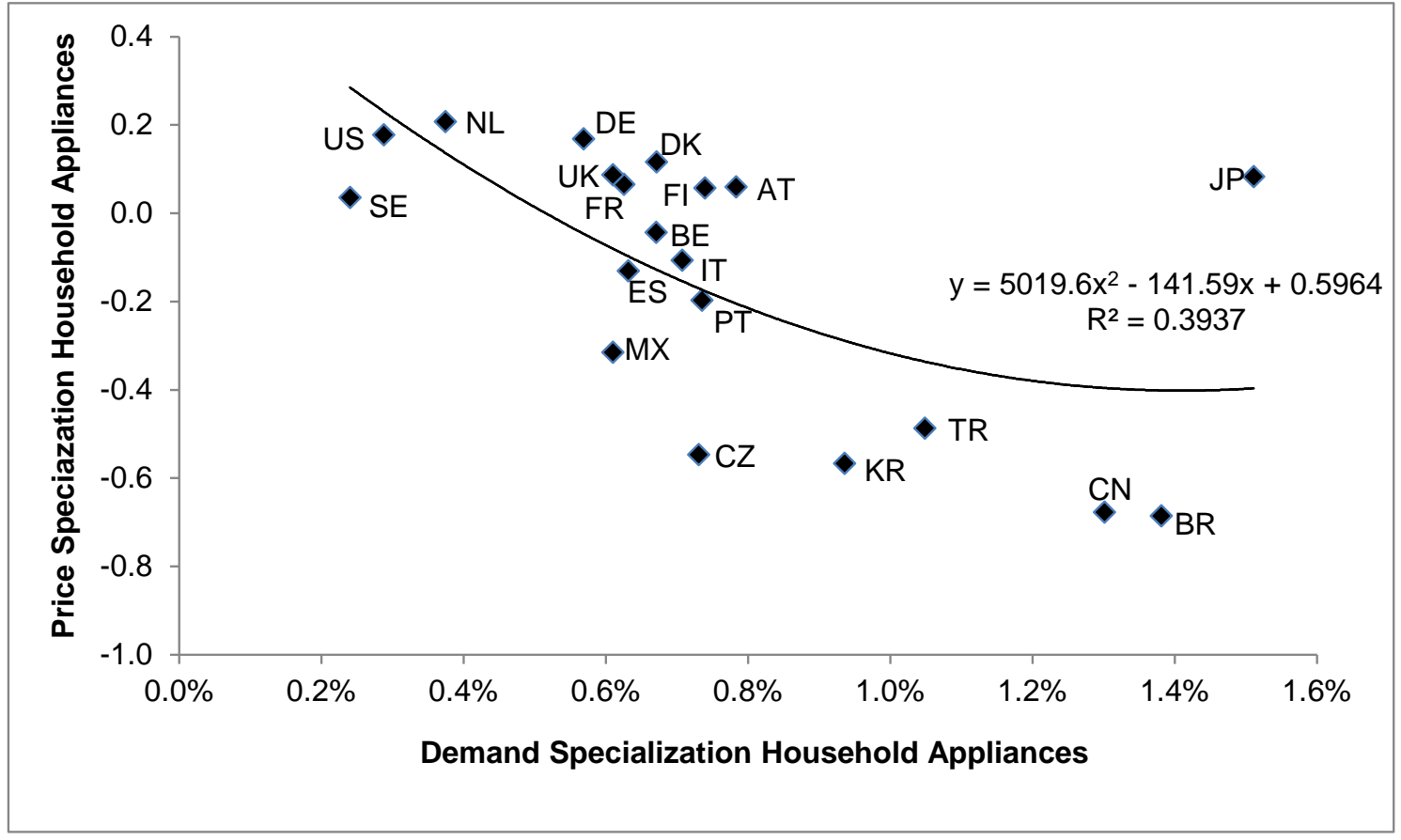

Remark: the demand advantage for Thailand is very low. It was omitted from the analysis, because of its huge leverage effect on the regression line. Source: Eurostat/OECD PPP-Statistics; Worldbank ICP 2011; Penn World Tables.

In Figure 4, especially the countries China (CN), Korea (KR), Thailand (TH), Turkey (TK) and Germany (right upper quadrant), show not only an above average export advantage (compared to the average export share of the top-20 export nations) but also an above average international market structure advantage. The exports can be realized simultaneously to a number of markets. Manufacturers of these markets are somehow able to face global competition. 
Figure 4: Market Structure Advantage and Export Advantage

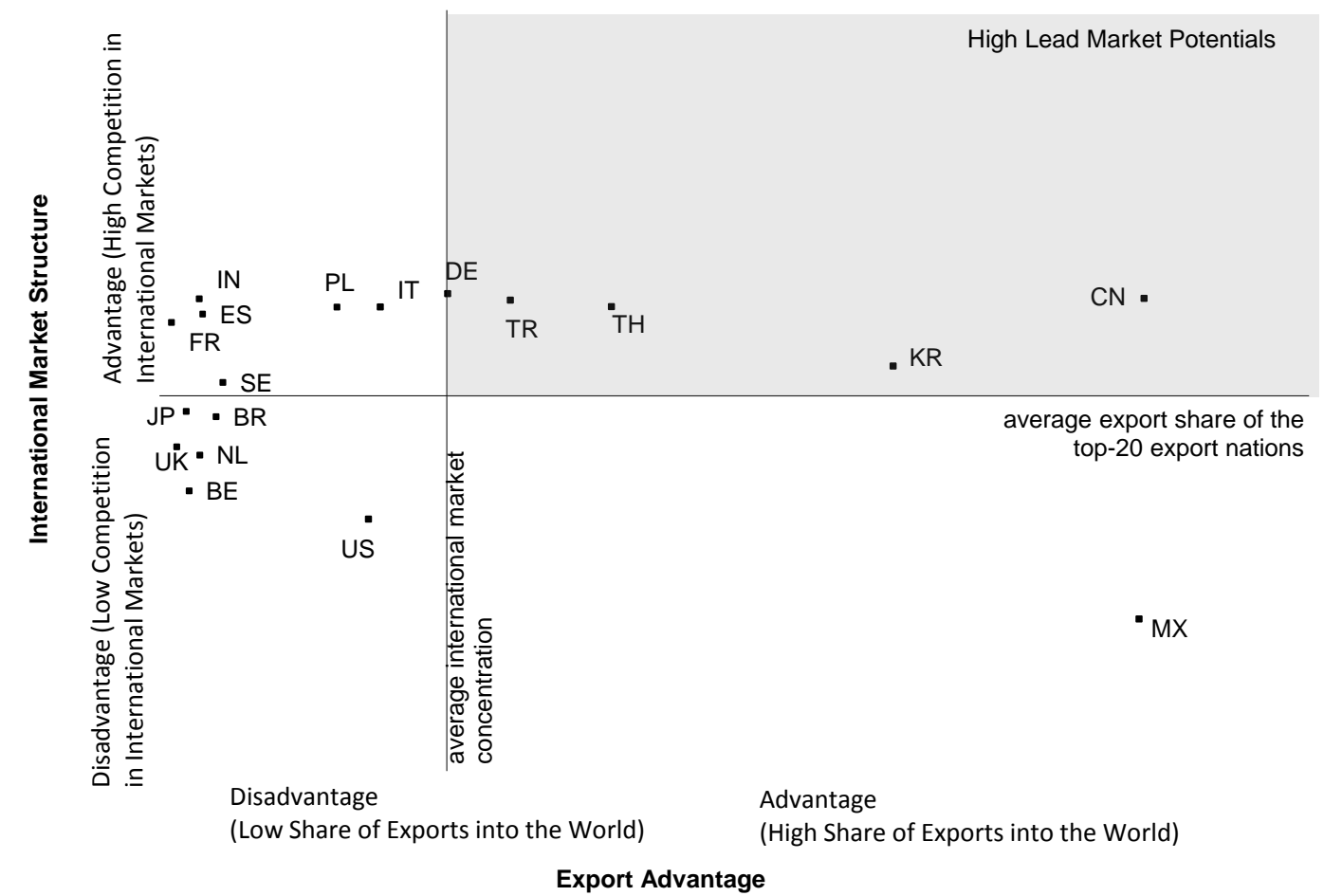

Source: UN Comtrade Database.

Regarding the transfer advantage, Table 1 shows that shares of worldwide patents in the field of household appliances are limited to only a small number of countries. As South Korean producers have on average between 2003 and 2007 about 30 percent of world shares, followed by German manufacturers with 26 percent. Far behind follows Italy (13 percent), the USA (9 percent), and Japan (5 percent). Only the German (46), South Korean (96) and Italian (89) producers show an above average RPA. All other mentioned countries have below average RPA values. In summary it can be stated that important innovations in energy efficiency are implemented by German and South Korean manufacturers. For both countries, all indicators to describe the transfer advantage are positive.

Table 1: Average world shares for patents in the field of Household Appliances for the years 2003 to 2007

\begin{tabular}{lrrrrrrrr} 
Period & US & DE & JP & IT & KR & CN & IN & RoW* $^{*}$ \\
\hline $\begin{array}{l}1995- \\
1999\end{array}$ & $10.04 \%$ & $35.81 \%$ & $3.93 \%$ & $33.19 \%$ & $3.93 \%$ & $0.00 \%$ & $0.00 \%$ & $13.10 \%$ \\
$2003-$ & & & & & & & & \\
2007 & $8.90 \%$ & $26.13 \%$ & $4.52 \%$ & $13.14 \%$ & $30.08 \%$ & $1.27 \%$ & $0.71 \%$ & $15.25 \%$ \\
\hline \multicolumn{7}{l}{$\begin{array}{l}\text { Source: Calculation of Fraunhofer ISI. } \\
\text { *Rest of the World }\end{array}$}
\end{tabular}


Finally, Figure 5 shows that the USA, the EU and Korea have a high regulatory advantage. The EU emphasized for a long time mandatory comparative energy labels and rather late MEPS. The opposite situation can be observed in China, where the state controlled the market through MEPS, while mandatory energy labels were introduced rather late.

Figure 5: Mandatory Comparative Energy Labels and MEPS for Refrigerators

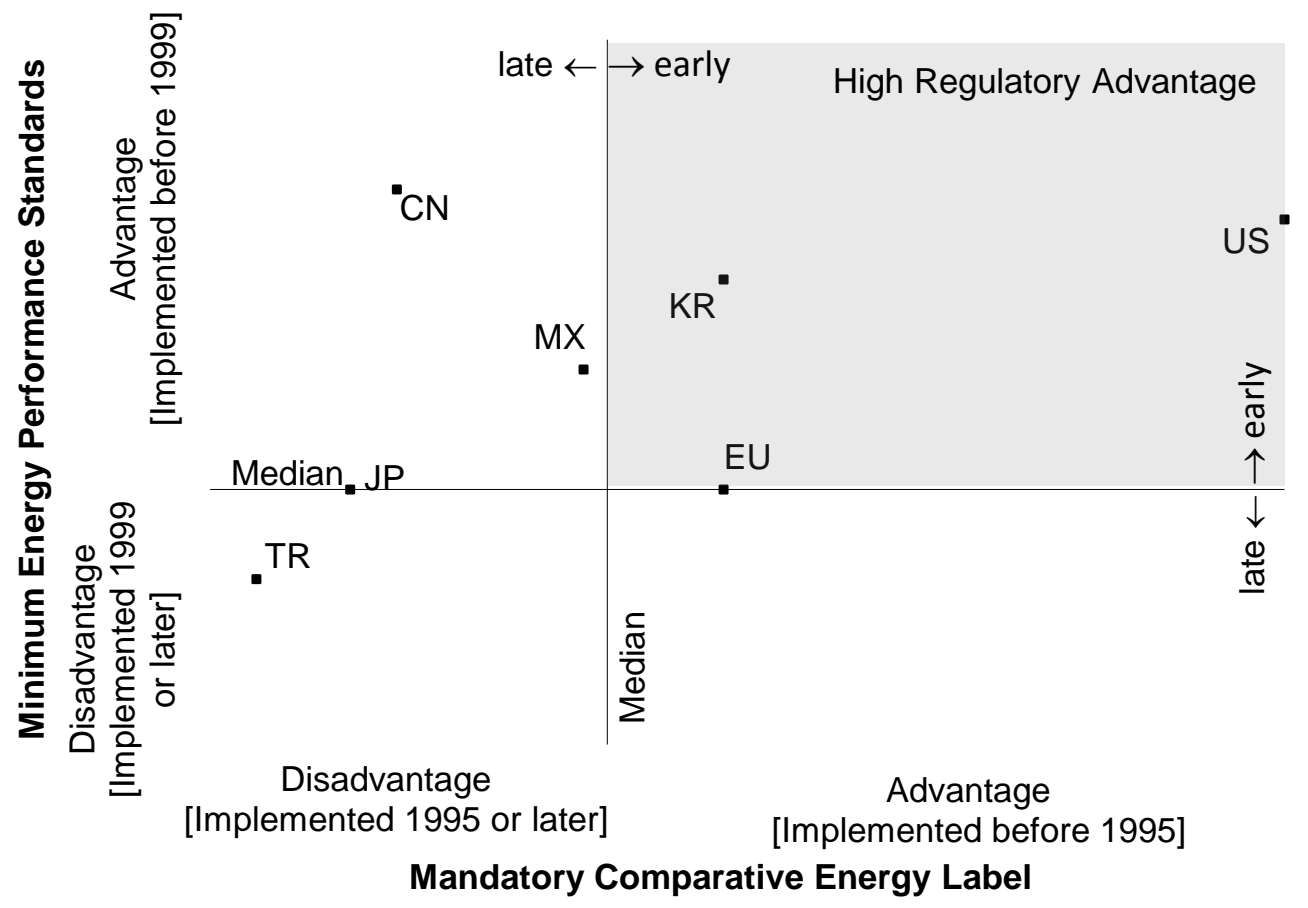

Source: Harrington/Damnics(2004), Energy Charter Secretariat (2009), CLASP (2012).

Interestingly, Japan does not belong to the countries with a regulatory advantage, although in 1999, Japan's Ministry of Economy, Trade and Industry introduced the "Top Runner Programme" which has a high international reputation as dynamic and ambitious energy-efficiency regulation. Its main goal was the reduction of energyrelated emissions in the fields of consumption and mobility of private households. The principal idea of the programme is the so-called "maximum standard value system" that means the efficiency standard to be achieved is aligned along the consumption values of the currently most energy efficient products available on the market (Rennings et al., 2008, 160).

However, the effects of energy efficiency of the Top Runner Programmes vary according to the product sub categories. In the volume categories 401 to 450 litres of electric refrigerators, the minimum standards were achieved very early, whereas in the categories of 141 to 250 litres, the increase in efficiency was implemented very slowly (SEA, 2005, 56). 
There are two reasons why the low efficiency increase of Japanese refrigerators did not lead to export success for the Japanese appliance industry. The product design aims especially at Japanese user practices, which are hardly compatible with European or worldwide demands. Furthermore, the minimum efficiency standard orients itself along similar available products on the Japanese market and not according to the most energy efficient products on the world market (SEA, 2005, 56).

\section{Firm perspectives}

To validate our results with real world lead markets strategies of firms, we carried out four interviews with leading firms in the refrigerator producing industry. We choose two technological leaders as interview partners, BSH Bosch and Siemens Home Appliances $\mathrm{GmbH}$ from Germany, and the Swedish firm Electrolux Household Appliances $\mathrm{GmbH}$ (AEG). We also talked to two firms which have a reputation for reasonable cost appliances, Indesit Company S.p.A. from Italy and Arçelik A.Ş. (BEKO) from Turkey. From the perspective of $\mathrm{BSH}$, energy efficient household appliances are markets where first and second mover advantages can be realized: first mover advantages with high-tech energy efficient appliances, second mover advantages with low cost products. Our interview partner from BSH regards his home market Germany as the market with the highest lead market potentials as the Korean market is rather isolated. Italy is only counted as a competitive supplier of parts of refrigerators, and customers in China and Thailand currently demand cheap and less innovative products. According to BSH, only Turkey has upcoming lead market potentials (Salmen, 2012).

Therefore, BSH was able to achieve a technological leadership together with other German firms in this sector. For the implementation of this technology leadership, the company focuses on the energy-conscious customers and on the political measures that define strict MEPS: "Due to the great potential for energy saving in the household appliance sector, it would be worth if politicians provided incentives here. The core message for a new energy efficiency policy could be summarised as: explain, promote, apply penalties and provide leadership. [...] We therefore strongly support the dynamic updating of the energy label criteria. Above all, the nomenclature for energy standards must be clearer, allowing distinctions to be identified at a glance. [...] It would be more effective to ban inefficient appliances" (BSH Bosch and Siemens Household Appliances $\mathrm{GmbH} 2012,30$ ). Apart from that, politics should offer consumers more incentives to switch to energy efficient products - concludes our interview partner. To sum up: BSH is in favour of more ambitious and binding energy efficiency standards.

Overall, the technological developments of producers in other countries are being observed very closely. While the Chinese producers are regarded as manufacturers of cheap appliances, Japanese producers manufacture on the same technological level as the European producers, however, with a very small range of products and missing sales capability. The greatest strategic competition comes from Turkish producers (especially BEKO), which gain ground as second mover on the European market especially in Germany - with very good energy efficient products (Löb, 2012). 
From the perspective of the Italian producer Indesit, energy efficiency of refrigerators is only one of many buying criteria of customers. Indesit uses this variety for its strategy of innovation: The company tries to deliver the best cost-benefit-ratio and wants to be "one of the best producers concerning the diversity of all costumer needs" (Falcioni and Ziller, 2012). A technological leadership in energy efficiency is explicitly not the aim because Indesit finds such innovations still too costly for the consumer. Energy efficient equipment needs sometimes 7 to 10 years to pay-off (Falcioni and Ziller, 2012).

An important second mover on the refrigerator market is the Turkish producer Arçelik A.Ş. (BEKO). Having a reputation for low cost appliances, the firms surprised also with innovative, eco-efficient solutions in the past. Due to the strict energy efficiency regulations in Europe, developments on this market are observed very closely. From BEKO's point of view there will be no competition for these innovations from China or Korea. Products from China are being regarded as low cost and low quality. Korea represents an average cost and quality segment. Japanese producers show a great potential for innovations in energy efficiency, but they still fail due to missing sales capability of Japanese producers. Drivers of innovation in energy efficiency in all countries are rather the costs for energy (life-cycle costs) than the labeling schemes (Sender, 2012).

BEKO is a second mover although the firm had success in the field of energy efficiency. For this purpose, companies in lead markets were acquired. For example, through the acquisition of the firm Blomberg, Arçelik A.Ş. was able to integrate knowhow about heat-pump driers into their company. BEKO's strategy shows clearly that the Turkish home market does not have to play the pioneering role in technological innovations. It is rather the case that the focus on the lead markets allows a producer of an emerging country - like Arçelik A.Ş. from Turkey - to realize second mover advantages (Sender, 2012).

\section{Conclusions and Limitations}

The following table summarises the lead market potentials of different countries. One can see that Germany has the most lead market advantages in the refrigerator producing industry, followed by Korea and Italy. First mover advantages for high-tech energy efficient appliances can be realised on the German market. This is backed by high energy efficiency standards in Europe which diffuse after some years to other countries. In countries that do not have sufficient lead market potentials, product innovations must be targeted to fit the preferences of users in the lead market. The screening of the lead market can take on varying degrees of intensity. These range from simply making use of listening posts in the lead market to testing and/or launching new products. A good way for a company to establish ties with a lead market is via producers with long experience on the Lead Market. This can be realized through a simple sales cooperation or a merger with a local producer of the lead market. Compared to establishing a new 
subsidiary in a potential Lead Market, cooperation with an existing company has the advantage that it already has longstanding relationships with customers and can offer considerable insight into conditions on the lead market.

Table 2: Top-five-Lead Market countries for energy efficient refrigerators

\begin{tabular}{|c|c|c|c|c|c|c|c|}
\hline \multirow[b]{2}{*}{ Country } & \multicolumn{6}{|c|}{ Lead Market Potentials } & \multirow{2}{*}{$\begin{array}{l}\text { LM Advan- } \\
\text { tages }\end{array}$} \\
\hline & Price & Demand & Export & Transfe & $\begin{array}{l}\text { Mark } \\
\text { Struct }\end{array}$ & $e^{\text {Regulation }}$ & \\
\hline Germany & 1 & 1 & 1 & 1 & 1 & 1 & 6 \\
\hline Korea & 0 & 0 & 1 & 1 & 1 & 1 & 4 \\
\hline Italy & 1 & 1 & 0 & 0 & 1 & 1 & 4 \\
\hline Denmark & 1 & 1 & 0 & 0 & 0 & 1 & 3 \\
\hline France & 0 & 1 & 0 & 0 & 1 & 1 & 3 \\
\hline
\end{tabular}

Note: +1 : Above average advantage; 0 : Not above average

There are a number of other possible lag market strategies to ensure that adequate attention is paid to the lead market:

- Developing an innovation on the lag market but taking into account customerspecific preferences of the lead market.

- Developing dual-use innovations, which satisfy demand both on the lag and on the lead market.

- Avoid technological designs that would be atypical on the lead market.

Our research also needs to acknowledge limitations of the chosen approach. As a consequence of our definition of the household appliances industry it needs to be kept in mind that the lead market advantages identified refer to the aggregate sector. It may well be that lead market advantages within a sector vary from one product group to another. Another limitation refers to the relatively short time series of data available which hampers a comparison of the indicators over time. The main reason for this is that PPP and expenditure data are not available for more than one year (2005). Future research should thus try to put our results into perspective with other markets and their potential as lead markets.

\section{Acknowledgements}

We appreciate funding from the project "Lead Market Strategies: First Mover, Early Follower, Late Follower" (funded by the German Ministry of Research and Education under the Program "Science for Sustainability, Economics and Sustainability"). 


\section{References}

Bartlett, C.A., Ghoshal, S. (1990): Managing innovation in the transnational corporation. In: Bartlett, C., Doz, Y. and Hedlund, G. (eds.): Managing the global firm, London, 215-255.

Beise, M. (2001): Lead Markets: Country specific Success Factors of the Global Diffusion of Innovations, ZEW Economic Studies, Vol. 14, Heidelberg.

Beise, M., Cleff, T., Heneric, O. and Rammer, C. (2002): Lead Market Deutschland. Zur Position Deutschlands als führender Absatzmarkt für Innovationen - Endbericht, ZEW-Dokumentation No. 02-02, Mannheim.

Beise, M., Rennings, K. (2005): Lead Markets and Regulation: A Framework for Analyzing the International Diffusion of Environmental Innovation. In: Ecological Economics 52/1, 5-17.

BMU (Bundesministerium für Umwelt, Naturschutz und Reaktorsicherheit) (2009): GreenTech made in Germany 2.0., Bonn.

BMU/UBA (Bundesministerium für Umwelt, Naturschutz und Reaktorsicherheit / Umweltbundesamt) (2011): Report on the Environmental Economy 2011, Facts \& Figures for Germany, Bonn.

BSH Bosch und Siemens Hausgeräte GmbH (2012): Sustainability Report 2011. Top Performance. With Responsibility, Munich.

CEC - (Commission of the European Communities) (2006): European Competitiveness Report 2006: Economic reforms and competitiveness: key messages from the European Competitiveness Report 2006 COM(2006) 697 final.

CIC (Center for International Comparisons of Production, Income and Prices) (n.Y.): Penn World Tables, https://pwt.sas.upenn.edu.

CLASP (Collaborative Labeling and Standards Program) (2012): Making appliance energy efficiency the new global standard, Website, http://www.clasponline.org/ResourcesTools/Tools/SL Search/SL SearchResults ?p=refrigeration.

Cleff, T., Grimpe, C., Rammer, C. (2011): Lead Markets in the European Textile Industry - Implications for European Innovation Policy, in: Bacher, U. et al. (Eds.): Interdisciplinary Management Research VII, Osijek 2011, 807-830.

CNIS (China National Institute of Standardization) (2010): White paper for the energy efficiency status of China energy-use products (2010), Beijing.

CNIS (China National Institute of Standardization) (2011): White paper for the energy efficiency status of China energy-use products (2011), Beijing.

Energy Charter Secretariat (2009): Policies that Work. Introducing Energy Efficiency Standards and Labels for Appliances and Equipment, Brussels.

Eurostat/OECD (2012): Eurostat-OECD Methodological Manual on Purchasing Power Parities. Luxembourg.

Falcioni, P., Ziller, F. (2012): Telephone interview, Mannheim and Ancona, $21^{\text {st }}$ of December 2012. Mimeo 
Harrington, Lloyd, Melissa Damnics (2004): Energy Labelling and Standards Programs Throughout the World. The national Appliance and Equipment Energy Efficiency Committee, NAEEEC Report 2004/24, Victoria.

Levitt, T. (1983): The Globalisation of Markets, Harvard Business Review Vol. 61 (3), pp. 92-102.

Löb, S. (2012): Telephone interview, Mannheim and Nuremberg, $17^{\text {th }}$ of December 2012. Mimeo

Odyssee (n.Y.): Energy Efficiency Indicators in Europe, http://www,odysseeindicators.org.

Porter, M. E. (1986): Changing Patterns of International Competition, California Management Review 28 (2), 9-40.

Porter, M.E. (1990): The Competitive Advantage of Nations, New York.

Rennings, K., C. Rammer, U. Oberndorfer, K. Jacob (2008): Instrumente zur Förderung von Umweltinnovationen, Umwelt, Innovation, Beschäftigung Bd. 02/08, Umweltbundesamt / Bundesministerium für Umwelt, Naturschutz und Reaktorsicherheit, Berlin.

Rennings, K., Cleff, T. (2011): First and second mover strategy options for pioneering countries on environmental markets - From national lead market to combined lead market and lead supplier strategies. Working Paper No. 5 within the project "Lead Markets" funded under the BMBF Programme WIN 2, Mannheim.

Rennings, K., Smidt, W. (2010): A Lead Market Approach Towards the Emergence and Diffusion of Coal-fired Power Plant Technology, Politica Economia XXVII, n.2, $301-327$.

Salmen, C. (2012): Telephone interview, Mannheim and Munich, $1^{\text {st }}$ of October 2012. Mimeo

SEA, Swedish Environmental Protection Agency (2005), The Top Runner Program in Japan - its effectiveness and implications for the EU, Stockholm. (http://www.naturvardsverket.se/bokhandeln/pdf/620-5515-1.pdf; 09.11.06).

Sender, N. (2012): Telephone interview, Mannheim and Neu-Isenburg, $17^{\text {th }}$ of December 2012. Mimeo

Tiwari, R., Herstatt, C. (2011): Role of 'Lead Market' Factors in Globalization of Innovation: Emerging Evidence from India \& its Implications, in: Proceedings of IEEE International Technology Management Conference (IEEE-ITMC), June 27-30, 2011, San José (USA).

UK Department for Energy and Climate Change (2012): Energy price statistics 2012, https://www.gov.uk/government/organisations/department-of-energy-climatechange/series/digest-of-uk-energy-statistics-dukes.

UN (United Nations) (2012): United Nations Commodity Trade Statistics Database, New York, http://comtrade.un.org/ .

US Energy Information Administration (2012): http://www.eia.gov/. 
Waheeduzzaman, A. N. M. (2011): Are Emerging Markets Catching Up With the Developed Markets in Terms of Consumption, Journal of Global Marketing, 24 (2), 136-151.

Walz, R., F. Marscheider-Weidemann (2011): Technology-specific absorptive capacities for green technologies in Newly Industrialized Countries. International Journal of Technology and Globalization, Vol. 5, Nos. 3,4, pp. $212-229$.

Worldbank ICP (International Comparison Programme) (2011): The International Comparison Programme,

http://siteresources.worldbank.org/ICPEXT/Resources/ICP 2011.html . 